\title{
Konsep Perilaku Agresif Siswa
}

\author{
Alifia Fernanda Putri \\ Universitas Negeri Padang \\ Correspondence author e-mail: alifia.fernanda@gmail.com
}

\begin{abstract}
Abstrak: Dalam fase perkembangan, remaja mengalami banyak tantangan dalam menjalani kehidupannya, baik dalam diri maupun di luar diri terutama di lingkungan sosial. Tantangan dari dalam diri seperti perubahan fisik yang sangat menonjol yang memerlukan penyesuaian agar tidak timbul kesulitan bagi remaja itu sendiri. Tantangan dari lingkungan misalnya: perlakuan dari orang tua dan orang dewasa lainnya tidak yang terkadang memperlakukan remaja sebagai anak-anak dan pada saat lain menuntut remaja itu bertingkahlaku sebagai orang dewasa. Naskah ini akan mengenalkan konsep dasar agresif siswa meliputi: konsep agresif, aspek agresif, jenis agresif dan faktor yang mempengaruhi agresif. Semoga ini dapat digunakan sebagai salah satu rujukan.
\end{abstract}

Kata kunci: Perilaku agresif, siswa

Article History: Received on 25/01/2019; Revised on 25/02/2019; Accepted on 12/03/2019; Published Online: 30/03/2019.

PENDAHULUAN

Dalam fase perkembangan, remaja mengalami banyak tantangan dalam menjalani kehidupannya, baik dalam diri maupun di luar diri terutama di lingkungan sosial. Tantangan dari dalam diri seperti perubahan fisik yang sangat menonjol yang memerlukan penyesuaian agar tidak timbul kesulitan bagi remaja itu sendiri. Tantangan dari lingkungan misalnya: perlakuan dari orang tua dan orang dewasa lainnya tidak yang terkadang memperlakukan remaja sebagai anak-anak dan pada saat lain menuntut remaja itu bertingkahlaku sebagai orang dewasa. Dengan demikian timbulnya perilaku-perilaku yang kurang baik pada kondisi tertentu perilaku tersebut dapat mengganggu orang lain. Sesuai dengan pendapat Elida Prayitno (2006:7), mitos yang sering dipercaya tentang ciri remaja yang sedang berkembang adalah pemunculan tingkah laku yang negatif, seperti suka melawan, gelisah, periode badai, tidak stabil, dan berbagai laber buruk lainnya.

Perilaku negatif yang ditunjukkan remaja tersebut adalah perilaku agresif, yaitu tindakan yang dilakukan secara sengaja pada individu lain sehingga mengakibatkan sakit fisk dan psikis pada individu lain. Agresif adalah perilaku seseorang yang menyebabkan luka fisik atau luka psikologis pada orang lain atau mengakibatkan kerusakan pada benda. Kematangan emosi pada remaja cenderung belum stabil, sering meledak-ledak, dan sulit dikontrol. Hal ini disebabkan oleh tidak terpenuhinya tuntutan mereka, misal: 
terjadinya perkelahian atau tawuran remaja. Ini juga disebabkan karena remaja belum bisa mengontrol emosi dan mereka ingin melampiaskan kemarahan mereka. Pada hal belum tentu masalah yang menyebabkan tauran tersebut adalah masalah besar, kebanyakan masalah yang timbul hanya karena saling ejek dan kesalahpahaman, dan dari hal tersebut mulai memancing amarah dan terjadi tindakan agresif.

Linda L. Davidoff (1991) mengemukakan perilaku agresif remaja dipengaruhi oleh beberapa faktor yaitu: 1) faktor biologis yang mempengaruhi perilaku agresif yaitu gen, sistem otak, dan kimia darah, dan 2) faktor lingkungan yang mempengaruhi perilaku agresif remaja yaitu kemiskinan, aninomitas, amarah, pengaruh kelompok teman sebaya, dan bentuk pendisiplinan yang keliru.

Kecenderungan perilaku agresif pada remaja terjad karena berbagai hal yang melatarbelakangi dan diperoleh remaja saat berinteraksi dengan lingkungannya. Hasil interaksi yang berupa informasi yang akhirnya terbentuk menjadi pengetahuan yang diyakini remaja. Tempat interaksi yang pertama bagi remaja adalah keluarga. Seperti yang dikemukakan oleh Gertrudge Jaegar (dalam Idianto, 2004:119) bahwa peranan agen sosialsialisasi dalam sistem keluarga pada tahap awal sangat besar karena anak sepenuhnya berada dalam lingkungan keluarganya terutama orang tuanya sendiri. Di tengah keluarga anak mengenal makna cinta dan kasih sayang, simpati, loyalitas, ideologi, bimbingan, dan pendidikan. Keluarga memberikan pengaruh dan pembentukan watak dan kepribadaian anak serta menjadi unit sisial terkecil yang memberikan pondasi primer bagi perkembangan anak. Baik biruknya struktur keluarga akan berdampak pada perkembangan jiwa dan jasmani pada anak.

\section{PEMBAHASAN}

Agresivitas Siswa

Pengertian Agresif

Agresif berasal dari kata "agresi". Agresi dapat didefinisikan sebagai perilaku atau kecenderungan perilaku yang diniati untuk menyakiti orang lain, baik secara fisikm verbal, maupun psikologis. Agresif menurut Robert Baron (dalam E. Koeswara, 1998:5) adalah tingkah laku yang ditunjukkan untuk melukai dan mecelakakan individu lain yang tidak menginginkan datangnya tingkah laku tersebut. Atkinson \& Hilgard (1983:58) menjelaskan agresi adalah perilaku yang secara sengaja bermaksud melukai orang lain (secara fisik dan verbal dan menghacurkan harta benda).

Menurut Sofyan S. Willis (2010:121) jika dipandang dari definisi operasional agresi adalah hasil dari proses kemarahan yang memuncak, sedangkan dari definisi motivasional perbuatan agresif adalah perbuatan yang bertujuan untuk menyakiti orang lain. Selanjutnya Moore dan Fine (dalam E. Koeswara, 1988:5) mengatakan bahwa agresif sebagai tingkah laku kekerasan secara fsik ataupun secara verbal terhadap individu lain atau terhadap objek-objek.

Berdasarkan pendapat sejumlah ahli tersebut, dapat disimpulkan bahwa agresivitas pada siswa merupakan perilaku yang ditunjukkan siswa yang dimaksudkan untuk melukai, menyakiti, atau merugikan orang lain, baik secara verbal, fisik, maupun merusak harta benda yang dapat menyebabkan luka fisik maupun psikis pada orang lain 
dalam ha ini orang lain yang dimaksud adalah guru, teman di sekolah, dan orang-orang di sekitarnya.

Aspek-Aspek Agresif

Tergolong agresi atau tidaknya suatu perilaku yang ditampilkan oleh individu dilihat dari aspek perilaku yang ditampilkan tersebut. Atkinson \& Hilgard (1983:121) menjelaskan tiga aspek perilaku agresi yang sering timbul pada diri individu yaitu:

a. Aspek fisik. Individu yang cenderung menggunakan kekerasan fisik dalam melampiaskan kemarahan dan emosi yang muncul dari dalam diri dan itu ditujukan kepada individu lain yang dianggap tidak menyenangkan atau mengadi sumber dari memarahan/emosi.

b. Aspek verbal. Aspek ini ditunjukkan individu dalam bentuk pelaksanaan atau ucapan terhdap individu lain yang dianggap tidak menyenangkan. Wujud perilaku yang ditampilkan dari aspek ini adalah seperti cacian, makian, umpatanm dan perilaku yang terkesan menyudutkan terhdap individu lain, sehingga berakibat pada luka psikis individu yang menjadi sasaran.

Merusak/menghancurkan harta benda milik orang lain. Aspek ini diwujudkan dalam bentuk pengerusakan harta benda milik individu lain dan secara tidak langsung melukai individu yang menjadi korban dalam bentuk kerugian dan trauma psikologis.

Jadi dapat dipahami bahwa agresivitas pada diri individu dapat diidentifikasi berdasarkan perilaku yang ditunjukkan ketika berinteraksi dengan individu lain, yaitu perilaku yang membahayakan dengan bermaksud melukai atau menyakiti individu lain baik itu secara fisik, verbal maupun psikis.

\section{Jenis-jenis Agresif}

Dapat dipahami bahwa agresi bukan hanya sebatas perilaku yang bersifat fisik malainkan juga berupa agresi verbal yang ditunjukkan dalam bentuk ucapan kata-kata yang mengganggu/merusak individu lain secara fisik maupun psikis.

Menurut Berkowitz (dalam E. Koeswara. 1998:5) membedakan agresi dalam dua macam yaitu:

a. Agresi instrumental, merupakan agresi yang dilakukan oleh organisme atau individu sebagai alat atau cara mencapai tujuan tertentu.

b. Agresi benci, merupakan agresi yang dilakukan semata-mata sebagai pelampiasan keinginan untuk melukai atau menyakitim agresi tanpa tujuan selain untuk menimbulkan efek kerusakan, kesakitan, atau kematian pada sasaran atau korbannya.

Berdasarkan uraian di atas dapat dipahami bahwa agresivitas juga dapat ditunjukkan dalam bentuk emosi tinggi dan agresi instrumental yang diindikasikan berbeda sebagai sarana untuk mencapai tujuan di samping kejahatan. 


\section{Faktor-faktor Penyebab Agresif}

Menurut Andi Mapiere (2000:98) faktor-faktor yang menjadi penyebab agresif meliputi:

a. Kondisi pribadi remaja yaitu kelainan yang dibawa sejak lahir baik fisik maupun psikis, lemahnya kontrol diri terhadap pengaruh lingkungan, kurang mampu menyesuaikan diri terhadap pengaruh lingkungan, kurang mampu menyesuaikan diri dengan lingkungan dan kurangnya dasar keagamaan.

b. Lingkungan rumah dan keluarga yang kurang memberikan kasih sayang dan perhatian orang tua sehingga remaja mencarinya dalam kelompok sebayanya, kurangnya komunikasi sesama anggota keluarga, status ekonomi keluarga yang rendah, ada penolakan dari ayah maupun ibu, serta keuarga yang kuran harmonis.

c. Lingkungan masyarakat yang kurang sehat, seperti kurangnya fasilitas pendidikan pada masyarakat, kurangnya pengawasan terhadap remaja serta pengaruh normanorma baru yang ada di luar.

d. Lingkungan sekolah, seperti kurangnya fasilitas pendidkan sebagai tempat penyaluran bakat dan minat remaja, kurangnya perhatian guru, tata cara disiplin yang terlalu kaku atau norma-norma pendidikan yang kurang diterapkan.

\section{KESIMPULAN}

Berdasarkan artikel ini mengenai "konsep perilaku agresif siswa" dapat disimpulkan bahwa tempat pendidikan pertama yang diterima oleh anak dan juga lingkungan yang sangat berpengaruh terhadap pertumbuhan serta pembentukan karakter dan tingkah laku yang ditampilkan anak dalam bersosialisasi dalam lingkungan masyarakat maupun sekolah. Berdasarkan fenomena yang terjadi ada beberapa anak yang bertindak agresif terhdap teman maupun kepada gurunya di sekolah. Tindakan agresif yang ditampilkan baik berupa tindakan fisik maupun secara verbal. Oleh sebab itu perilaku yang ditampilkan anak sangat tergantung dari kondisi lingkungan.

\section{SARAN}

Masih banyaknya perilaku agresif siswa disekolah serta disini guru pembimbing atau guru bk berperan untuk mengatasi perlaku agresif siswa disekolah. Serta artikel ini masih jauh dari kata sempurna, saya mohon kepada pembaca untuk memberi kritik dan sarannya untuk memperbaiki artikel ini, tidak lupa saya berharap agar artikel ini dapat diterima oleh pembaca dikemudian hari.

\section{References}

Elida Prayitno. (2011). Psikologi Keluarga. Padang: FIP UNP.

Koeswara. (1998). Agresi Manusia. Bandung: Erasco.

Linda L. Davidof, dkk. (1991). Psikologi Suatu Pengantar. Jakarta: Erlangga.

Hurlock, E. B. (1993). Psikologi Perkembangan. Alih Bahasa: Dra. Istiwidayanti dan Drs. Soedjarwo, Msc. Jakarta: Erlangga.

Mimi Ariyanti Eka Saputri. (2006). "Hubungan antara Konsep Diri dengan Agresivitas Siswa". Skirpsi tidak diterbitkan. Padang: Universitas Negeri Padang. 
Moch. Sochib. (2010). Pola Asuh Orang Tua untuk Membantu Anak Mengembangkan Disiplin Diri. Jakarta: Rineka Cipta.

Sudarso. (1995). Kenakalan Remaja: Prevensi Rehabilitasi dan Resosialoisasi. Edisi Kedua: Jakarta: Rineka Cipta.

Sofyan S Willis. (2011). Remaja dan Masalahnya Mengupas Berbagai Bentuk Kenakalan Remaja, Narkoba, Free Sex, dan Pemecahannya. Bandung: Alfabeta.

Triyono. (2016). “Kontribusi Dukungan Orangtua dan Persepsi Siswa terhadap Tingkat Aspirasi Pendidikan Lanjutan serta Implikasinya dalam Bimbingan dan Konseling". Tesis tidak diterbitkan. Padang: FIP UNP 